\title{
TECHONOLGY OF Qualea grandiflora MART. (VOCHYSIACEAE) SEEDS
}

\author{
Sara Dousseau ${ }^{1}$, Amauri Alves de Alvarenga ${ }^{2}$, Lúcio de Oliveira Arantes $^{3}$, Izabel de Souza Chaves ${ }^{4}$,Eduardo Valente Avelino ${ }^{5}$
}

(received: November 20, 2010; accepted: September 28, 2012)

\begin{abstract}
Qualea grandiflora Mart. (Vochysiaceae), commonly known as "pau-terra", is an arborous species native to the Brazilian savannah which possess commercial interests, as it can be used either as an ornamental or as a medicinal plant. "Pau-terra" can also be used in the heterogeneous reforestation of areas which are destined for restoration of permanent preservation degraded areas. Propagation studies with this species are scarce, being necessary then further clarification regarding the factors that influences the germination process. In this context, the objective of this work was to evaluate the influence of different temperatures, substrates and light conditions on seed germination. We selected light brown seeds which were subjected to different interactions between temperatures $\left(15-25,20-30,25\right.$ and $30^{\circ} \mathrm{C}$ ), substrate (paper, sand and vermiculite) and light (light and dark). All seeds were later dryincubated at $32^{\circ} \mathrm{C}$ for 3,6 and 12 hours. After treatments, seeds were kept in BOD at $58 \% \mathrm{RH}$ and the following parameters were calculated: germination $(\% \mathrm{G})$ and germination speed index (GSI); the formation of normal and abnormal seedlings and the number dead seeds. Interaction was observed for all variables. In the optimum temperature range, the seeds behaved as photoblastic neutral or indifferent. Under alternating temperatures, darkness enhanced the germination, especially when combined with the lower temperatures. We noted that the sowing in sand, at $25^{\circ} \mathrm{C}$, allowed the maintenance of suitable combinations of germination and seedling development. With respect to desiccation tolerance, "pau-terra" seeds presented an orthodox behavior, with a linear increase of the vigor as function of drying.
\end{abstract}

Key words: Light, temperature, substrate, drying, orthodox.

\section{TECNOLOGIA DE SEMENTES DE Qualea grandiflora MART. (VOCHYSIACEAE)}

RESUMO: Qualea grandiflora Mart. (Vochysiaceae), conhecida como pau-terra, é uma espécie arbórea nativa do cerrado brasileiro que apresenta interesse comercial, como ornamental e medicinal, podendo ainda ser empregada em reflorestamentos heterogêneos, destinados á recomposição de áreas degradadas de preservação permanente. Estudos de propagação com essa espécie são escassos, sendo necessários maiores esclarecimentos quanto aos fatores que influenciam no processo germinativo. Nesse contexto, objetivouse avaliar a influência de diferentes temperaturas, substratos e condições de luminosidade na germinação de sementes de pau-terra. Foram selecionadas sementes de coloração marrom clara e submetidas a interação entre temperaturas $\left(15-25,20-30,25\right.$ e 30 $\left.{ }^{\circ} \mathrm{C}\right)$, substratos (sobre papel, entre areia e entre vermiculita) e luz. (claro e escuro), e a secagem em estufa a $32{ }^{\circ} \mathrm{C}$, por 3 , 6 e 12 horas. Após o tratamento, as sementes foram mantidas em BOD com 58\% UR e calculados os parâmetros germinabilidade (\%G) e indice de velocidade de germinação (IVG), formação da plântula normal e anormais e de sementes mortas. Foi observada interação para todas as variáveis analisadas. Na faixa de temperatura ótima, as sementes apresentaram comportamento fotoblástico neutro ou indiferente. Sob temperaturas alternadas, o escuro favoreceu a germinação, principalmente quando em combinação com a temperatura mais baixa. A semeadura entre areia a $25^{\circ} \mathrm{C}$ permite a manutenção de combinações adequadas para a germinação e desenvolvimento da plântula. Com relação à tolerância a dessecação, as sementes de pau terra apresentam comportamento ortodoxo, havendo um incremento linear do vigor em função da secagem.

Palavras-chave: Luz, temperatura, substrato, secagem, ortodoxa.

\section{INTRODUCTION}

Qualea grandiflora Mart. (Vochysiaceae) is popularly known as "pau-terra", "pau-terra-do-campo", "pau-terra-do-cerrado", "pau-terra-da-folha-larga", "ariavá", among others (CORRÊA, 1978). It is an arborous species native to the Brazilian savannah, which occurs in the gallery forests and in the savannah, widely distributed

\footnotetext{
${ }^{1}$ Agronomist, DSc student in Plant Physiology - Universidade Federal de Lavras/UFLA - Departamento de Biologia - Cx. P. 3037 37200-000 - Lavras, MG, Brazil - saradousseau@yahoo.com.br

${ }^{2}$ Agronomist, Professor DSc in Plant Biology - Universidade Federal de Lavras/UFLA - Departamento de Biologia - Cx. P. 3037 37200-000 - Lavras, MG, Brazil - amauriaa@dbi.ufla.br

${ }^{3}$ Agronomist, MSc in Plant Breeding - Universidade Federal de Lavras/UFLA - Departamento de Biologia - Cx. P. 3037 - $37200-000$ Lavras, MG, Brazil - lucio_arantes@yahoo.com.br

${ }^{4}$ Biologist, DSc student in Plant Physiology - Universidade Federal de Lavras/UFLA - Departamento de Biologia - Cx. P. 3037 - $37200-000$ Lavras, MG, Brazil - izabelchaves@yahoo.com.br

${ }^{5}$ Under-graduate student in Biological Sciences - Universidade Federal de Lavras/UFLA - Departamento de Biologia - Cx. P. 3037 37200-000 - Lavras, MG, Brazil - duavelino@yahoo.com.br
} 
from the Legal Amazon to São Paulo, Minas Gerais, Goias and Mato Grosso, being usually found on high, dry and well drained terrains (ALMEIDA et al., 1998; LORENZI, 2000). This species possess commercial interests, as it can be used either as an ornamental or as a medicinal plant, as well as a timber source and for environmental purposes.

It is a heliophytic and selective xerophytic, being pioneer species adapted to poor lands, which enables it to be exploited in heterogeneous reforestation of areas which are destined for restoration of permanent preservation degraded areas (LORENZI, 2000). It is honey and by cooking its green fruits, a dye can be extracted (ALMEIDA et al., 1998). The crude extract of its bark is antibacterial (ALVES et al., 2000) and the hydroalcoholic extract of the bark has antiulcer action (HIRUMA-LIMA et al., 2006). The hydroalcoholic extract of its leaves is an analgesic with anticonvulsant potential (GASPI et al., 2006). The ethanol extract of the leaves also possess antioxidant (SOUSA et al., 2007) and antibacterial effects (AYRES et al., 2008).

Silvicultural knowledgement of that specie are scarce, most of which is summarized by Felippe (1990) e Melo et al. (1979). Both suggested the occurrence of seed dormancy, which was overcome with the complete withdrawal of the integument or by keeping the seeds in a storage cloth-bag at room temperature for a period of 6 months.

Seed germination may be defined as a sequence of physiological events that occur before radicle protrusion in non-dormant soaked seeds, being the step that involves the establishment of seedlings, called the post-germination event. The physiological state of the seeds differs considerably in the germination and post-germination processes in terms of gene expression profiles and desiccation tolerance (NONOGAKI, 2006). It is therefore possible that besides the differences in the germination and post-germination metabolism, that the responses to environmental conditions might also be different.

The germination process is regulated by many environmental factors such as moisture, oxygen, temperature, light and nutrients (SEO et al., 2009). Temperature, light of photoblastic positive seeds, and water are the most important environmental factors that promote seed germination (SOCOLOWSKI et al., 2008). The seeds of photoblastic positive behavior are dependent of the action of phytochromes, for its turn, changes according variation of temperature (FRANKLIN, 2009; HESCHEL et al., 2007; SIMÃO et al., 2007). The phytochromes modulate the endogenous levels of gibberellin (GA) and abscisic acid (ABA) and also the responsiveness to GA (SEO et al., 2009). The temperature influences the growth potential of the embryo as well and hormonal levels, especially ABA and GA (NONOGAKI, 2006; PENFIELD, 2008; TOH et al., 2008; YAMAGUCHI, 2008) so, there is a relationship between light intensity and temperature (SEO et al., 2009).

The substrate is a complex factor that influences, in a variety of ways, the germination and post-germination processes. While choosing the material for the substrate, one should take into consideration then, the size of the diaspores and its requirements in relation to moisture and light; especially considering density, water absorbency and retention, aeration, absence of pathogens and toxic substances. The ideal substrate should also provide some sort of ease for seedling evaluation.

The seeds water content is another factor that decisively influences the germination process and longevity. With respect to drying tolerance, seeds the are classified physiologicaly into tree groups, the orthodox, intermediate and recalcitrant. The orthodox seeds have a strong desiccation at the end of ripening on the mother plant and are able to maintain its germination potential for long periods of storage in dry state. On the other hand, intermediate and recalcitrant seeds have high water content at maturity, are intolerant to desiccation and begin its germination immediately after the ripening stage, without passing through the phases of drying and metabolic quiescence. Several studies have been undertaken to elucidate the possible need or sensitivity of the seeds to the desiccation process, being of great importance to quantify this behavior (ANGELOVICI et al., 2010; FISHER, 2008; MASETTO et al., 2008).

Therefore, due to the increasable demand for propagation methods of medicinal species of the Brazilian savannah (DOUSSEAU et al., 2007; ZAIDAN; CARREIRA, 2008), there is an urgent need of further elucidation of the factors that influences the germination of these species, including "pau-terra". The objective of this work was to evaluate the influence of different temperatures, substrates, light intensity and desiccation on germination of "pauterra" seeds.

\section{MATERIAL AND METHODS}

The experiments were conducted at the Laboratory of Plant Growth and Development, a sector of Plant Physiology, Department of Biology, Federal University of Lavras, MG, Brazil. The fruits of pau-terra were collected

Cerne, Lavras, v. 19, n. 1, p. 93-101, jan./mar. 2013 
from 10 selected mother trees in a natural population located in the municipality of Ijaci (MG), from August 2007 to October 2009. The fruits were collected immediately before the beginning of dehiscence; i.e. when they exhibited a small opening at the distal portion to the petiole; and left on a concrete yard during the day and collected at night for three consecutive days to allow the seeds release. The seeds were selected and only those that had a light brown integument were used for all experiments (FELIPPE, 1990). The winged expansion of the seeds was removed manually, either for the biochemical analysis or for the physiological assessments. The moisture content was determined according prescriptions of Brasil (2009).

To evaluate the interaction between light intensity, temperature and substrate on seed germination and postgermination were tested differents substrates (Germtest ${ }^{\circledR}$ paper and sand in acrylic gerboxes and Germtest ${ }^{\circledR}$ paper roll) combined with periods of exposure the light (12 h photoperiod and dark) and temperatures (15-25, 20-30, 25 and $30^{\circ} \mathrm{C}$ ). The dark condition was achieved by engaging the gerboxes in aluminum foil and black polyethylene bags, being the germinating behavior evaluated under green light.

The test was conduced in (B.O.D.) chamber, with approximately $58 \% \mathrm{RH}$. The evaluations were performed daily for a period of 22 days, using as techological criteria a $0.9 \mathrm{~cm}$ protrusion, being $0.5 \mathrm{~cm}$ of primary root and of 0.4 of hypocotyls; and post-germination, normal seedlings (FERREIRA et al., 2001), as depicted in Figure 1. From these data we determined the germination $(\% \mathrm{G})$ and germination vigour by speed index (GSI) calculated according to Maguire (1962). At 40 days after sowing, we evaluated the overall percentage of normal seedlings (\%NS) and abnormal (\%AS). We used a completely randomized $3 \times 2 \times 4$ factorial scheme with four replications of 25 seeds per treatment. Statistical analysis was performed by using the statistical program SISVAR (FERREIRA, 1999). The data did not suffer any kind of transformation. We performed an analysis of variance and means were compared by the Tukey test $(p \leq 0.05)$.

To evaluate the desiccation tolerance, seeds were dried in an oven at $32^{\circ} \mathrm{C}$ for 3,6 and 12 hours. After each drying period, it was determined the moisture content; and the physiological quality of the seeds was evaluated by means of the emergency. The seeds were disinfected with $1 \%$ Cercobin for 5 minutes, sown in gerboxes in substratum autoclaved sand and kept at $25^{\circ} \mathrm{C}$ and $12 \mathrm{~h}$ photoperiod (ideal conditions for germination and normal seedling formation identified in the previous experiment).
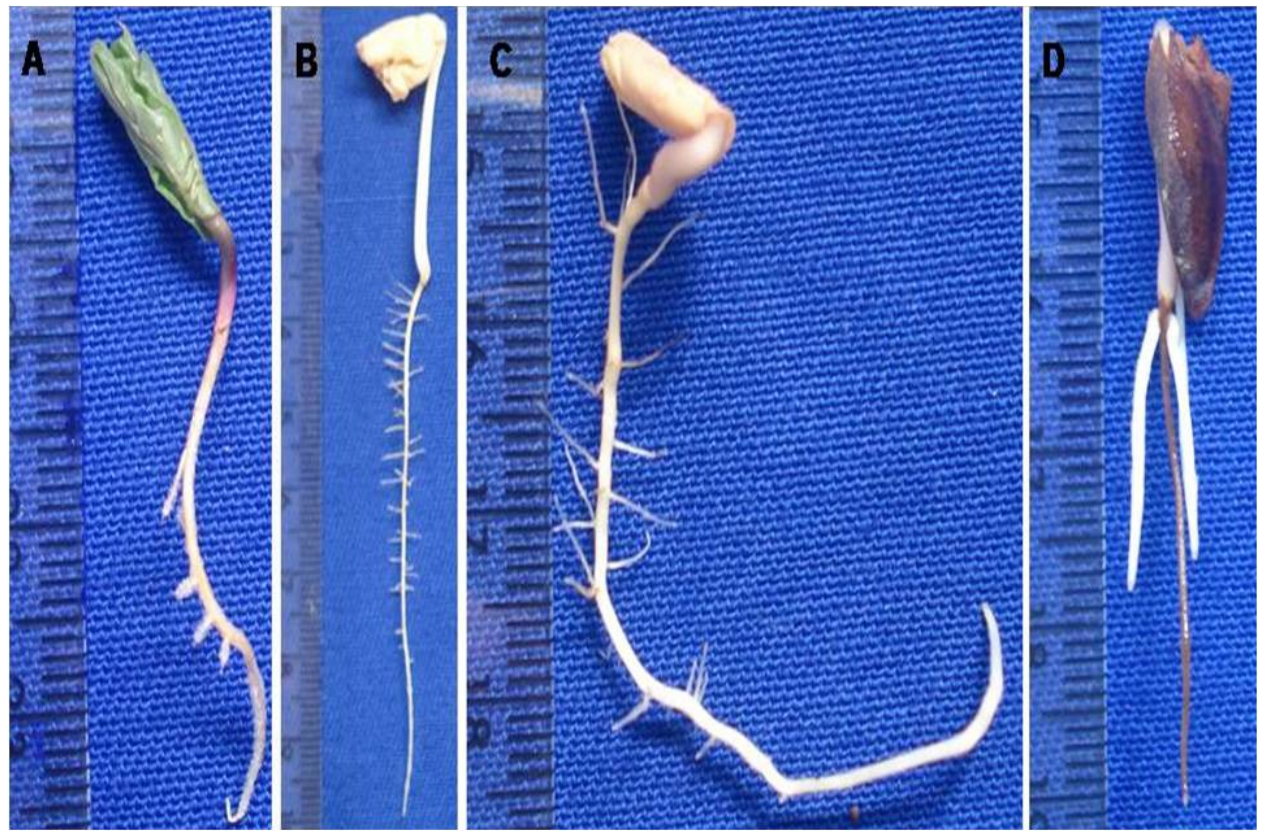

Figure 1 - Appearance of seedlings of Qualea grandiflora. Normal A-, B-roll dark; C dark sand and paper, D-abnormal.

Figura 1 - Aspecto das plântulas de Qualea grandiflora. A-Normal; B-Rolo no escuro; C areia e papel no escuro; D-anormal. 
The criteria used for germination was $0.9 \mathrm{~cm}$ protrusion, being $0.5 \mathrm{~cm}$ of primary root and of 0.4 of hypocotyls. The germination was evaluated for 22 days and determined the germination $(\% \mathrm{G})$ and germination vigour by speed index (GSI) calculated according to Maguire (1962). At 40 days after sowing, we evaluated the overall percentage of normal seedlings (\%NS) and abnormal (\%AS).

The experiment was conducted in completely randomized design with four replications of 25 seeds per treatment. We also performed an analysis of variance and the means were compared by polynomial regression ( $\mathrm{p} \leq 0.05$ ), using the statistical program Sisvar (FERREIRA, 1999).

\section{RESULTS AND DISCUSSION}

The Table 1 represent a summary of the analysis of variance (ANOVA) for seed germination characteristics. For the $\% \mathrm{G}$ double interaction was observed between the studied factors, while for the GSI, \%NS and \%AS triple interaction was significant.

Temperatures of $25^{\circ} \mathrm{C}$ and $30^{\circ} \mathrm{C}$ provided the highest values of $\% \mathrm{G}$ and GSI, regardless of the presence or absence of light (Table 2 and 3). In the range of optimum temperature, the seeds behaved as photoblastic neutral or indifferent.

However, alternating temperatures, even though it has not favored the germination process, as it caused a reduction in the $\% \mathrm{G}$ and GSI (Table 2 and 3), altered the photoblastic response. At $15-25^{\circ} \mathrm{C}$, the seeds germinated in the dark had a higher $\% \mathrm{G}$ and GSI, than those germinated in the presence of light. At $20-30 \%{ }^{\circ} \mathrm{C}$ the $\% \mathrm{G}$ did not differ regarding the presence and absence of light, however, the germination rate was higher in the dark. It seems that under less suitable conditions, darkness enhanced germination, mainly in the alternately condition that contained the lower temperatures. Koefender et al. (2009) also found an increase in the germination of seeds of Calendula officinalis L, when germinated in the dark under thermal stress. According Zaidan and Carreira (2008), seeds of most of the arborous species, native to the savannah, germinate between $20^{\circ} \mathrm{C}$ and $30^{\circ} \mathrm{C}$ and are indifferent to light. Alternate temperatures not always favor the germination of seeds, however, often alter the light sensitivity in some species (GODOY; TAKAKI, 2004), while in others not (SIMÃO; TAKAKI, 2008).

Regarding the interaction of light with the substrate, we found that seeds that germinated on paper were indifferent to light, while darkness seems to have favored the root protrusion in seeds germinated on sand (Table 2 and 4). In the roll, only the $\% \mathrm{G}$ differed in response to light, being also higher in the dark conditions. Both in light and in darkness, the highest values of $\% \mathrm{G}$ and GSI were observed in seeds germinated on paper and on the roll, which did not differ, while that on sand the numbers were lower when compared to the other substrates.

Table 1 - Summary of the analysis of variance (ANOVA) for germination (\%G), speed index (GSI), percentage of normal seedlings (\%NS) and abnormal (\%AS) of seed Qualea grandiflora.

Tabela 1 - Resumo da análise de variância (ANAVA) para a germinação (\%G), índice de velocidade de germinação (GSI), porcentagem de plântulas normais $(\% N S)$ e anormais $(\% A S)$ de sementes de Qualea grandiflora.

\begin{tabular}{|c|c|c|c|c|c|}
\hline \multirow{2}{*}{ Source of variation } & \multirow{2}{*}{ GL } & \multicolumn{4}{|c|}{ Mean square } \\
\hline & & $\% \mathrm{G}$ & GSI & $\% \mathrm{NS}$ & $\% \mathrm{AS}$ \\
\hline Light (L) & 1 & $3420,09 * *$ & 0,16 & $988,17 * *$ & $1980,17 * *$ \\
\hline Temperature $(\mathrm{T})$ & 3 & $4213,26^{* *}$ & $4,63 * *$ & $371,28 * *$ & $4264,17 * *$ \\
\hline Substrate (S) & 2 & $10658,01 * *$ & $9,64 * *$ & $40737,50 * *$ & $25588,50 * *$ \\
\hline $\mathrm{L} * \mathrm{~T} * \mathrm{~S}$ & 6 & 296,93 & $0,16^{* *}$ & $905,50 * *$ & $537,72 * *$ \\
\hline $\mathrm{L} * \mathrm{~T}$ & 3 & $1915,10^{* *}$ & $0,83 * *$ & $3297,50 * *$ & $1159,72 * *$ \\
\hline $\mathrm{L} * \mathrm{~S}$ & 2 & $871,59 * *$ & $0,26 * *$ & $352,17 * *$ & $918,17 * *$ \\
\hline $\mathrm{T} * \mathrm{~S}$ & 6 & $2690,01^{* *}$ & $0,34 * *$ & $1120,61 * *$ & $1828,50 * *$ \\
\hline Error & 72 & 154,7 & 0,05 & 58,06 & 61,06 \\
\hline Coefficient of variation (\%) & & 15,18 & 13,95 & 13,64 & 24,14 \\
\hline
\end{tabular}

**, * Significant respectively, at $1 \%$ and $5 \%$ probability of the test $\mathrm{F}$.

Cerne, Lavras, v. 19, n. 1, p. 93-101,jan./mar. 2013 
Table 2 - Germination (G\%) of seeds of Qualea grandiflora under different light intensity, temperature and substrate. Breakdown of interactions between light and temperature and between light and substrate.

Tabela 2 - Germinabilidade (\%G) de sementes de Qualea grandiflora, submetidas a diferentes condições de luminosidade, temperaturas e substratos. Desdobramento das interações entre luz e temperatura e entre luz e substrato.

\begin{tabular}{ccc}
\hline \multirow{2}{*}{ Temperatures $\left({ }^{\circ} \mathrm{C}\right)$} & \multicolumn{2}{c}{ Light intensity } \\
\cline { 2 - 3 } & Light & Dark \\
\hline $15-25$ & $49 \mathrm{Bc}$ & $78 \mathrm{Ab}$ \\
$20-30$ & $68 \mathrm{Ab}$ & $75 \mathrm{Ab}$ \\
25 & $90 \mathrm{Aa}$ & $93 \mathrm{Aa}$ \\
30 & $94 \mathrm{Aa}$ & $96 \mathrm{Aa}$ \\
\hline Substrates & & \\
\hline On sand & $48 \mathrm{Bb}$ & $73 \mathrm{Ab}$ \\
On paper & $94 \mathrm{Aa}$ & $96 \mathrm{Aa}$ \\
Paper roll & $84 \mathrm{Ba}$ & $95 \mathrm{Aa}$ \\
\hline
\end{tabular}

Means followed by same letter do not differ by Tukey test ( $\mathrm{p}<0.05)$. Uppercase letters and lowercase compare the line in the column.
According to the RAS (BRASIL, 2009), on paper (OP) is recommended for small and light sensitive seeds, while that between paper roll (BPR) for large seeds, which prefer moist environments and are not sensitive to light. On the other hand, the sand is a substrate used alternatively to confirm the seedling evaluation in case of doubt, when phytotoxic symptoms appear or when the evaluation of a sample is impractical due to excess of infection (BRASIL, 2009).

Regarding the interaction between substrate and temperature, it can be seen that for $\% \mathrm{G}$, only in alternating temperatures response to the substrates differed, with lower values on sand (Table 4).

In this substrate, the $\% \mathrm{G}$ and the GSI were higher at constant temperatures and lower in the alternating (Table 4 and 3). For seeds germinated on paper there were no differences for $\% \mathrm{G}$, regarding the thermal regimes (Table 4), however, to GSI (Table 3), the behavior was the same as that we found on the sand, i.e. higher values at constant temperatures and lower in the alternate. Unlike other substrates, for seeds germinated on the roll, the $\% \mathrm{G}$ was higher above $30^{\circ} \mathrm{C}$ and $20-30^{\circ} \mathrm{C}$ and lower below $15-25^{\circ} \mathrm{C}$;

Table 3 - Germination vigor by speed index (GSI), percentage of normal seedlings (\%NS) and abnormal (\%AS) of Qualea grandiflora seeds under different conditions of temperature, light and substrate. Decomposition of the triple interaction.

Tabela 3 - Índice de velocidade de germinação, porcentagem de plântulas normais e anormais de sementes de Qualea grandiflora, submetidas a diferentes condições de temperatura, luz e substrato. Desdobramento da interação tripla.

\begin{tabular}{|c|c|c|c|c|c|c|}
\hline \multirow{3}{*}{ Temperatures $\left({ }^{\circ} \mathrm{C}\right)$} & \multicolumn{6}{|c|}{ Substrates } \\
\hline & \multicolumn{2}{|c|}{ Paper roll } & \multicolumn{2}{|c|}{ On paper } & \multicolumn{2}{|c|}{ On sand } \\
\hline & Light & Dark & Light & Dark & Light & Dark \\
\hline \multicolumn{7}{|c|}{ IVG } \\
\hline $15-25$ & $0.93 a \mathrm{Ab}$ & $0.92 a \mathrm{Ab}$ & $0.66 c \mathrm{Bc}$ & $0.87 a b \mathrm{Abc}$ & $0.19 b \mathrm{Bd}$ & $0.71 \mathrm{bAc}$ \\
\hline $20-30$ & $0.93 a \mathrm{Ab}$ & $1.02 a \mathrm{Ab}$ & $0.87 a \mathrm{Ab}$ & $0.76 \mathrm{bAc}$ & $0.87 a \mathrm{Ac}$ & $0.71 b \mathrm{Bc}$ \\
\hline 25 & $1.00 \mathrm{bAb}$ & $0.88 \mathrm{bAb}$ & $1.35 a \mathrm{Aa}$ & $1.04 b \mathrm{Bab}$ & $1.50 a \mathrm{Aa}$ & $1.41 a \mathrm{Aa}$ \\
\hline 30 & $1.34 a \mathrm{Aa}$ & $1.34 a \mathrm{Aa}$ & $0.66 b \mathrm{Bc}$ & $1.08 \mathrm{bAa}$ & $1.20 a \mathrm{Ab}$ & $1.15 \mathrm{bAb}$ \\
\hline \multicolumn{7}{|c|}{$\% \mathrm{PN}$} \\
\hline $15-25$ & $8 \mathrm{Bc} b$ & $27 \mathrm{aCa}$ & $44 \mathrm{bB} b$ & $73 \mathrm{aB} a$ & $95 \mathrm{aA} a$ & $98 \mathrm{aA} a$ \\
\hline $20-30$ & $46 \mathrm{aB} a$ & $29 \mathrm{aB}$ & $57 \mathrm{abB} a$ & $41 \mathrm{bB} b$ & $97 \mathrm{aA} a$ & $94 \mathrm{aA} a$ \\
\hline 25 & $51 \mathrm{aC} a$ & $4 \mathrm{bB} b$ & $66 \mathrm{aB} a$ & $4 \mathrm{cB} b$ & $95 \mathrm{aA} a$ & $94 \mathrm{aA} a$ \\
\hline 30 & $40 \mathrm{aB} a$ & $32 \mathrm{aB} a$ & $11 \mathrm{cCb}$ & $36 \mathrm{Bb} a$ & $99 \mathrm{aA} a$ & $100 \mathrm{aA} a$ \\
\hline \multicolumn{7}{|c|}{$\% \mathrm{PA}$} \\
\hline $15-25$ & $74 \mathrm{aA} a$ & $71 \mathrm{aA} a$ & $53 \mathrm{bB} a$ & $22 \mathrm{bB} b$ & $0 \mathrm{aCa}$ & $2 \mathrm{aCa}$ \\
\hline $20-30$ & $53 \mathrm{bA} a$ & $66 \mathrm{aA} a$ & $41 \mathrm{bcA} a$ & $48 \mathrm{aB} a$ & $0 \mathrm{aB} a$ & $1 \mathrm{aC} a$ \\
\hline 25 & $48 \mathrm{bA} b$ & $64 \mathrm{aA} a$ & $32 \mathrm{cB} a$ & $0 \mathrm{cB} b$ & $0 \mathrm{aC} a$ & $0 \mathrm{aB} a$ \\
\hline 30 & $56 \mathrm{bB} a$ & $0 \mathrm{aB} b$ & $86 \mathrm{aA} a$ & $60 \mathrm{aA} b$ & $0 \mathrm{aC} a$ & $0 \mathrm{aB} a$ \\
\hline
\end{tabular}

Means followed by same letter do not differ by Tukey test $(\mathrm{p}<0.05)$. Capital letters compare light condition within each temperature and substrate. Lowercase letters compare temperature within each light condition and substrate. Italic lowercase letters compared substrate within each condition of light and temperature. 
Table 4 - Germination (G\%) of seeds of Qualea grandiflora under different light intensity, temperature and substrate. Breakdown of interactions between temperature and substrate.

Tabela 4 - Germinabilidade (\%G) de sementes de Qualea grandiflora, submetidas a diferentes condições de luminosidade, temperaturas e substratos. Desdobramento das interações entre temperatura e substrato.

\begin{tabular}{cccc}
\hline \multirow{2}{*}{ Temperatures $\left({ }^{\circ} \mathrm{C}\right)$} & \multicolumn{3}{c}{ Substrates } \\
\cline { 2 - 4 } & On sand & On paper & Paper roll \\
\hline $15-25$ & $39 \mathrm{Bb}$ & $91 \mathrm{Aa}$ & $75 \mathrm{Ab}$ \\
$20-30$ & $23 \mathrm{Bb}$ & $95 \mathrm{Aa}$ & $98 \mathrm{Aa}$ \\
25 & $88 \mathrm{Aa}$ & $98 \mathrm{Aa}$ & $90 \mathrm{Aa}$ \\
30 & $91 \mathrm{Aa}$ & $97 \mathrm{Aa}$ & $97 \mathrm{Aa}$ \\
\hline
\end{tabular}

Means followed by same letter do not differ by Tukey test ( $\mathrm{p}<0.05)$. Uppercase letters and lowercase compare the line in the column.

however, at $25^{\circ} \mathrm{C}$ the values did not differ between the thermal regimes (Table 4). The GSI of the seeds on this substrate was higher at $30^{\circ} \mathrm{C}$, followed by those at $25^{\circ} \mathrm{C}$ and $20-30^{\circ} \mathrm{C}$ that did not differ among them, and lower at $15-25^{\circ} \mathrm{C}$ (Table 3). Several other studies also reveal the interaction between substrate and temperature, with very distinct results between species (MARTINS et al., 2008; NOVEMBRE et al., 2007; PACHECO et al., 2006; SOUZA et al., 2007). For the root protrusion, it can be concluded that the best vigor expression is found when seeds germinate at 25 and $30^{\circ} \mathrm{C}$, on paper or on roll, in both lighting conditions.

In the post-germination process, as well as in the germination, we also observed a significant interaction for all factors studied (Table 3), however, with different response between the two processes. With regards to the relationship of the interaction for the percentage of normal seedlings, we found that the development of normal seedlings was affected differently in relation to temperature, light and substrate (Table 3).

At $25^{\circ} \mathrm{C}$ the percentage of normal seedlings was higher in light conditions, whereas at $15-25^{\circ} \mathrm{C}$ was higher in dark conditions (Table 3 ). As for the germination under heat stress, the dark favored the development of normal seedlings. On the other hand, at $30^{\circ} \mathrm{C}$ and $20-30^{\circ} \mathrm{C}$, there was no influence of light. The temperature of $25^{\circ} \mathrm{C}$ under light conditions provided the highest values, followed by $30^{\circ} \mathrm{C}$ and $20-30^{\circ} \mathrm{C}$, with lower values at $15-25^{\circ} \mathrm{C}$. In the dark, the values were higher at $30^{\circ} \mathrm{C}$ and $15-25^{\circ} \mathrm{C}$ and lower at $25^{\circ} \mathrm{C}$ and $20-30^{\circ} \mathrm{C}$. Darkness favored the development of abnormal seedlings at $25^{\circ} \mathrm{C}$ and decreased the rate of abnormal seedlings at $30^{\circ} \mathrm{C}$, while in alternating temperatures; there was no difference (Table 3 ). In the light, the greater percentage of abnormal seedlings was observed at $30^{\circ} \mathrm{C}$, followed by the other temperatures, which did not differ. On the other hand, in the dark, the highest percentage occurred at $25^{\circ} \mathrm{C}$ followed by $30^{\circ} \mathrm{C}$ and $20-30^{\circ} \mathrm{C}$ and lowest at $15-25^{\circ} \mathrm{C}$.

Regarding the interaction of light with the substrate, it can be seen that on sand the higher percentage of normal seedlings occurred in the light, while that on roll was in the dark (Table 3). On paper did not differ in response to light. In light, the highest percentage of normal seedlings was obtained for on sand and lower for on roll. However, paper does not differ from other substrates. On the other hand, in the dark, the values were higher for on sand, followed by on paper and by on roll (Table 3). We observed the appearance of abnormal seedlings, with malformation, in function of the type of substrate used (Table 3). Both on paper and on roll occurred intense formation of abnormal seedlings. In the dark, the highest percentage of abnormal seedlings was obtained on the roll, followed by on paper and on sand. In light, the highest values were obtained when we tested the seedling grown on roll and on paper, which did not differ. In the treatment on sand, practically no formation of abnormal seedlings was observed, independent of the luminosity.

That for root protrusion, most normal seedling occurred on sand, at constant temperatures and lower in the alternating (Table 3). On paper, the values were higher at $15-25^{\circ} \mathrm{C}$ and lower at $30^{\circ} \mathrm{C}$, while the other temperatures, promoted intermediate values. On roll the percentage of normal seedlings showed the same pattern as that observed for germination, i.e. higher at $30^{\circ} \mathrm{C}$ and $20-30^{\circ} \mathrm{C}$ and lower at $15-25^{\circ} \mathrm{C}$; however, at $25^{\circ} \mathrm{C}$ the values did not differ from other thermal regimes.

For normal seedlings, we observed that its formation on the sand was the lowest (Table 3). In alternating temperatures, the values of abnormal seedlings were higher on the roll, followed by on paper and on sand (Table 3 ). At $25^{\circ} \mathrm{C}$, the percentage was higher on the roll and on paper, which did not differ. At $30^{\circ} \mathrm{C}$, the percentage was higher on paper, followed by on the roll. On sand, the percentage of abnormal seedlings was lower on alternating temperatures in relation to the constant temperatures. On

Cerne, Lavras, v. 19, n. 1, p. 93-101, jan./mar. 2013 
paper, the highest percentage was observed at $30^{\circ} \mathrm{C}$ and lowest at $15-25^{\circ} \mathrm{C}$, while the other temperatures, promoted intermediate values. On the roll the percentage was higher at $30^{\circ} \mathrm{C}$ and $20-30^{\circ} \mathrm{C}$ and lower at $15-25^{\circ} \mathrm{C}$, however, at $25^{\circ} \mathrm{C}$ values did not differ from other thermal regimes. At sowing on paper, there was a higher occurrence of necrosis of main root, which often appear truncated and thicker, with thick hypocotyls with few secondary roots, being this effect intensified by the higher temperature $\left(30^{\circ} \mathrm{C}\right)$ and by presence of light, probably due to root dryness due to exposure to air. On roll, the effect was probably due to high humidity of this system, making seedlings abnormal with a higher proportion of necrosis of the main root, being that only at $15-25^{\circ} \mathrm{C}$, we observed a higher amount of truncated roots. It can be concluded then, that for normal seedling, the most favorable condition is the one that uses sand and that maintains temperature constant at $25^{\circ} \mathrm{C}$.

The moisture content was higher in seeds recently benefited $(12 \%)$ and lowered with drying, with values between 2 and 3\%, which did not differ (Figure 2). It was observed that $\% \mathrm{G}$ did not differed between the drying periods, with values varying between 90 and $100 \%$ and and all developed into normal seedlings. Regarding the GSI, there was a linear increase in the vigor as seed desiccation proceeded.

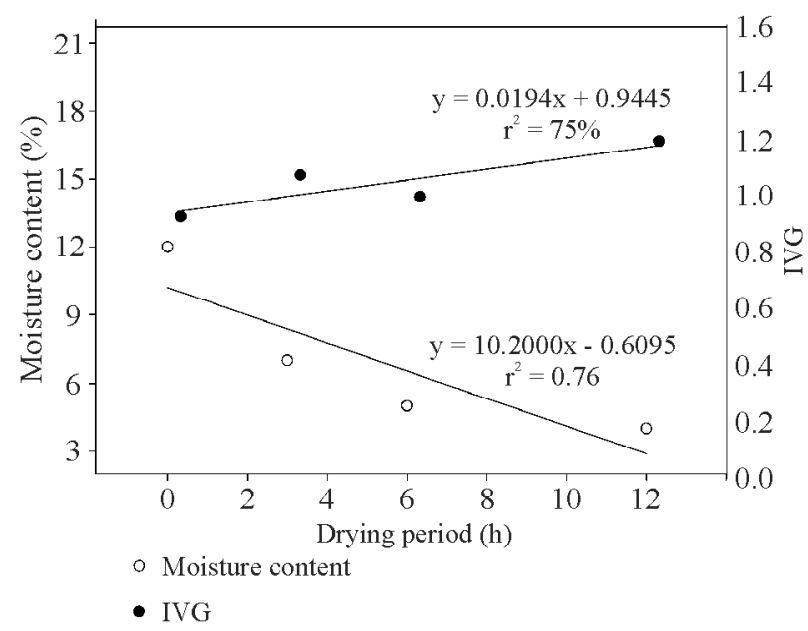

Figure 2 - Moisture content (\%M) and germination speed index (GSI) of the seeds of Qualea grandiflora, submitted to desiccation.

Figura 2 - Grau de umidade (\%U) e indice de velocidade de germinação (IVG) de sementes de Qualea grandiflora, submetidas a dessecação.
In recalcitrant seeds, a diverse range of damages is observed with drying (FARIA et al., 2004; MASETTO et al., 2008), while in orthodox seeds various mechanisms are activated to prevent such harms (ANGELOVICI et al., 2010; FISHER, 2008). In orthodox seeds, drying acts as a signal for the passage of the state of development to germination (ANGELOVICI et al., 2010; CATUSSE et al., 2008). With the results of our experiment, we can conclude that the "pauterra" seeds exhibit orthodox behavior in relation to desiccation.

\section{ACKNOWLEDGEMENTS}

This work was supported by the Brazilian National Research Council, CNPq, with the concession of a M.Sc. fellowship for the first and third authors, a research fellowship for the second author, and under-graduate fellowship to the fourth author.

\section{REFERENCES}

ALMEIDA, S. P.; PROENÇA, C. E. B.; SANO, S. M.; RIBEIRO, J. F. Cerrado: espécies vegetais úteis. Planaltina: EMBRAPA-CPAC, 1998. 464 p.

ALVES, T. M. A.; SILVA, A. F.; BRANDÃO, M.; GRANDI, T. S. M.; SMÂNIA, E. F. A.; SMÂNIA JÚNIOR, A.; ZANI,

C. L. Biological screening of Brazilian medicinal plants.

Memórias do Instituto Oswaldo Cruz, Rio de Janeiro, v. 95, n. 3 , p. $367-73$, maio/jun. 2000.

ANGELOVICI, R.; GALILI, G.; FERNIE, A. R.; FAIT, A. Seed desiccation: a bridge between maturation and germination. Trends in Plant Science, Oxford, v. 15, n. 4, p. 211-218, Feb. 2010.

AYRES, M. C. C.; ESCÓRCIO, S. P.; COSTA, D. A. da; CHAVES, M. H. Constituintes químicos das folhas de Qualea grandiflora: atribuição dos dados de RMN de dois flavonóides glicosilados acilados diastereoisoméricos. Química Nova, São Paulo, v. 31, n. 6, p. 1481-1484, set. 2008.

BRASIL. Regras para análise de semente. Brasília: MAPA/ ACS, 2009. 399 p.

CATUSSE, J.; JOB, C.; JOB, D. Transcriptome-and proteome-wide analyses of seed germination. Comptes Rendus Biologies, Paris, v. 331, n. 10, p. 815-822. Oct. 2008.

Cerne, Lavras, v. 19, n. 1, p. 93-101, jan./mar. 2013 
CORRÊA, M. P. Dicionário de plantas úteis do Brasil e exóticas cultivadas. Rio de Janeiro: Ministério da Agricultura/ Instituto Brasileiro de Desenvolvimento Florestal, 1978. v. 5.

DOUSSEAU, S.; ALVARENGA, A. A. de; CASTRO, E. M. de; ARANTES, L. de O.; NERY, F. C. Superação de dormência em sementes de Zeyheria montana Mart. Ciência e

Agrotecnologia, Lavras, v. 31, n. 6, p. 1744-1748, nov./dez. 2007.

FARIA, J. M. R.; LAMMEREN, A. A. M. van; HILHORST, H. W. M. Desiccation sensitivity and cell cycle aspects in seeds of Inga vera subsp. affinis. Seed Science Research, Wallingford, v. 14, p. 165-178, 2004.

FELIPPE, G. M. Qualea grandiflora: the seed and its germination. Revista Brasileira de Botânica, São Paulo, v. 13, p. 33-37, 1990.

FERREIRA, D. F. SISVAR: sistema de análises estatísticas. Versão 4.3. Lavras: UFLA, 1999.

FERREIRA, R. A.; DAVIDE, A. C.; TONETTI, O. A. O. Morfologia de sementes e plântulas de pau-terra (Qualea grandiflora Mart. - Vochysiaceae). Revista Brasileira de Sementes, Brasília, v. 23, n. 1, p. 116-122, 2001.

FISHER, K. M. Bayesian reconstruction of ancestral expression of the lea gene families reveals propagule-derived desiccation tolerance in resurrection plants. American Journal of Botany, Columbus, v. 95, n. 4, p. 506-515, 2008.

FRANKLIN, K. A. Light and temperature signal crosstalk in plant development. Current Opinion in Plant Biology, London, v. 12, p. 63-68, 2009.

GASPI, F. O. G.; FOGLIO, M. A.; CARVALHO, J. E.; MORENO, R. A. Pharmacological activities investigation of crude extracts and fractions from Qualea grandiflora Mart. Journal of Ethnopharmacology, Lausanne, v. 107, n. 1, p. 19-24, 2006.

GODOI, S.; TAKAKI, M. Effects of light and temperature on seed germination in Cecropia hololeuca Miq. (Cecropiaceae). Brazilian Archives of Biology and Technology, Curitiba, v. 47, n. 2, p. 185-191, June 2004.

HESCHEL, M. S.; SELBY, J.; BUTLER, C.; WHITELAM, G. C.; SHARROCK, R. A.; DONOHUE, K. A new role for

Cerne, Lavras, v. 19, n. 1, p. 93-101,jan./mar. 2013 phytochromes in temperature-dependent germination. New Phytologist, Cambridge, v. 174, n. 4, p. 735-741, Mar. 2007.

HIRUMA-LIMA, C. A.; SANTOS, L. C.; KUSHIMA, H.; PELLIZZON, C. H.; SILVEIRA, G. G.; VASCONCELOS, P. C. P.; VILEGAS, W.; SOUZA-BRITO, A. R. M. Qualea grandiflora, a Brazilian "Cerrado" medicinal plant presents an important antiulcer activity. Journal of Ethnopharmacol, Lausanne, v. 104, p. 207-214, 2006.

KOEFENDER, J.; MENEZES, N. L.; BURIOL, G. A.; TRENTIN, R.; CASTILHOS, G. Influência da temperatura e da luz na germinação da semente de calêndula. Horticultura Brasileira, Brasília, v. 27, p. 207-210, 2009.

LORENZI, H. Árvores brasileiras: manual de identificação e cultivo de plantas arbóreas nativas do Brasil. 4. ed. Nova Odessa: Plantarum, 2000. v. 1, 368 p.

MAGUIRE, J. D. Speed of germination-aid in selection and evaluation for seedling emergence and vigour. Crop Science, Madison, v. 2, p. 176-177, 1962.

MARTINS, C. C.; MACHADO, C. G.; CAVASINI, R. Temperatura e substrato para o teste de germinação de sementes de pinhão manso. Ciência e Agrotecnologia, Lavras, v. 32, n. 3, p. 863-868, maio/jun. 2008.

MASETTO, T. E.; FARIA, J. M. R.; DAVIDE, A. C.; SILVA, E. A. A. da. Desiccation tolerance and DNA integrity in Eugenia pleurantha O. Berg. (Myrtaceae) seeds. Revista Brasileira de Sementes, Brasília, v. 30, n. 1, p. 175-180, 2008.

MELO, J. T. de; RIBEIRO, J. F.; LIMA, V. L. G. de F. Germinação de sementes de algumas espécies arbóreas nativas do cerrado. Revista Brasileira de Sementes, Brasília, v. 1, n. 2, p. 8-12, 1979.

NONOGAKI, H. Seed germination: the biochemical and molecular mechanisms. Breeding Science, Tokyo, v. 56, p. 93-105, 2006.

NOVEMBRE, A. D. da L. C.; FARIA, T. C.; PINTO, D. H. V.; CHAMMA, H. M. C. P. Teste de germinação de sementes de sansão-do-campo (Mimosa caesalpiniaefolia Benth. Fabaceae-Mimosoideae). Revista Brasileira de Sementes, Brasília, v. 29, n. 3, p. 47-51, 2007. 
PACHECO, M. V.; MATOS, V. P.; FERREIRA, R. L. C.; FELICIANO, A. L. P.; PINTO, K. M. S. Efeito de temperaturas e substratos na germinação de sementes de Myracrodruon urundeuva Fr. All. (Anacardiaceae). Revista Árvore, Viçosa, v. 30, n. 3, p. 359-367, maio/jun. 2006.

PENFIELD, S. Temperature perception and signal transduction in plants. New Phytologist, Cambridge, v. 179, p. 615-628, 2008.

SEO, M.; NAMBARA, E.; CHOI, G.; YAMAGUCHI, S. Interaction of light and hormone signals in germinating seeds. Plant Molecular Biology, Dordrecht, v. 69, p. 463-472, 2009.

SIMÃO, E.; SOCOLOWSKI, F.; TAKAKI, M. The Epiphytic Cactaceae Hylocereus setaceus (Salm-Dick ex DC.) Ralf Bauer seed germination is controlled by light and temperature. Brazilian Archives of Biology and Technology, Curitiba, v. 50, p. 655-662, 2007.

SIMÃO, E.; TAKAKI, M. Efeito da luz e da temperatura na germinação de sementes de Tibouchina mutabilis (Vell.) Cogn. (Melastomataceae). Biota Neotropica, Campinas, v. 8, n. 2, p. 63-68, 2008.

SOCOLOWSKI, F; VIEIRA, D. C. M.; MASSANORI, T. Interaction of temperature and light on seed germination in
Tecoma stans L. Juss. ex Kunth (Bignoniaceae). Brazilian Archives of Biology and Technology, Curitiba, v. 51, p. 723730, 2008.

SOUSA, C. M. de M.; SILVA, H. R. e; VIEIRA-JÚNIOR, G. M.; AYRES, M. C. C.; COSTA, C. L. S. da; ARAÚJO, D. S.; CAVALCANTE, L. C. D.; BARROS, E. D. S.; ARAÚJO, P. B. de M.; BRANDÃO, M. S.; CHAVES, M. H. Fenóis totais e atividade antioxidante de cinco plantas medicinais. Química Nova, São Paulo, v. 30, n. 2, p. 351-355, mar./abr. 2007.

TOH, S.; IMAMURA, A.; WATANABE, A.; NAKABAYASHI, K.; OKAMOT, M.; JIKUMARU, Y.; HANADA, A.; ASO, Y.; ISHIYAMA, K.; TAMURA, N.; IUCHI, S.; KOBAYASHI, M.; YAMAGUCHI, S.; KAMIYA, Y.; NAMBARA, E.; KAWAKAMI, N. High temperatureinduced abscisic acid biosynthesis and its role in the inhibition of gibberellin action in Arabidopsis seeds. Plant Physiology, Bethesda, v. 146, p. 1368-1385, 2008.

YAMAGUCHI, S. Gibberellin metabolism and its regulation. Annual Review of Plant Biology, Palo Alto, v. 59, p. 225$251,2008$.

ZAIDAN, L. B. P.; CARREIRA, R. C. Seed germination in Cerrado species. Brazilian Journal of Plant Physiology, Piracicaba, v. 20, n. 3, p. 167-181, 2008. 
